О. В. Дехтярьова

\title{
ЛЕКСИЧНІ ЗАПОЗИЧЕННЯ В КОМПОНЕНТНОМУ СКЛАДІ ДІАЛЕКТНИХ ФРАЗЕОЛОГІЗМІВ (НА МАТЕРІАЛІ ХУДОЖНІХ ТВОРІВ ЗАХІДНОУКРАЇНСЬКИХ ПИСЬМЕННИКІВ КІНЦЯ ХІХ - ПОЧАТКУ ХХ СТ.)
}

Дехтярьова О. В. Лексичні запозичення в компонентному складі діалектних фразеологізмів (на матеріалі художніх творів західноукраїнських письменників кінця XIX - початку XX ст.).

У статті йдеться про діалектні фразеологічні одиниці 3 компонентамизапозиченнями, зафіксованими у художніх творах Л. Мартовича, В.Стефаника, Г. Хоткевича, М. Черемшини. Досліджуються взаємозв'язки української мови 3 іншими національними мовами, шляхи запозичення лексем та стилістичний потенціал діалектних фразеологічних одиниць.

Ключові слова: діалектна фразеологічна одиниця, запозичення, компонентний склад фразеологізмів, художній текст.

Дехтярева Е. В. Лексические заимствования в компонентном составе диалектных фразеологизмов (на материале художественных произведений западноукраинских писателей конца XIX - начала XX ст.).

В статье рассматривается диалектные фразеологизмы с компонентамизаимствованиями, зафиксированные в художественных произведениях Л. Мартовича, В. Стефаника, Г. Хоткевича, М. Черемшины. Исследуется взаимосвязь украинского языка с другими национальными языками, пути заимствования лексем, а также стилистический потенциал диалектных фразеологических единиц.

Ключевые слова: диалектная фразеологическая единица, заимствования, компонентный состав фразеологизмов, художественный текст.

С О. В. Дехтярьова, 2013. 
Dekhtyareva E. V. Lexical borrowings in the component structure of dialect idioms (on the material of the artistic works of the West Ukrainian writers of the end of XIX beginning of XX centuries).

The article is about the dialect phraseological units with the components-loanwords, which were recorded in works of art of L. Martovich, V. Stefanik, G. Hotkevich, M.Cheremshina. Interrelations of Ukrainian with other national languages, ways of loan of words and the stylistic potential of dialect phraseological units are investigated.

Key words: dialect phraseological unit, loanwords, component structure of phraseological units, art text.

У лінгвістичних працях другої половини XX ст. - початку XXI ст. спостерігаємо посилення уваги науковців до проблем, пов'язаних iз функціями, лінгвостилістичними потенціями, текстотвірними можливостями, прагматикою ФО як компонентів мовної тканини художніх творів (зокрема, праці Л. Г. Авксентьєва, I. С. Гнатюк, Ю. І. Кохана, Л. Г. Скрипник, А. П. Супрун, Л. Ф. Щербачук та ін.).

Особливе значення для дослідження національного фразеологічного фонду має вивчення функціонального потенціалу діалектної фразеології, поряд із фіксацією діалектних фразеологічних одиниць (далі - ДФО) у художніх творах, що становить, безперечно, історичну цінність як складник словесної культури українського народу.

ДФО протягом усієї історії українського народу акумулюють у собі інформацію різного роду. Вони відображають фонетичні, словотвірні, морфологічні, синтаксичні, лексичні особливості певного діалекту; репрезентують різноманітні відношення ФО i мовних особливостей регіонального, загальнослов' янського або європейського простору. Як одиниці словесної культури - вербалізують факти історії, побуту, фольклору, міфології українського народу. Тож зрозуміло, що грунтовне вивчення діалектної фразеології в художньому творі належить до важливих завдань сучасного мовознавства, оскільки й до сьогодні відсутні спеціальні праці, присвячені аналізу функціонування ДФО в художніх текстах.

Кінець XIX - початок XX ст. можна схарактеризувати як період найбільш активного збагачення лексико-фразеологічного складу i стилістичних можливостей української літературної мови, на формування якої впливало живе розмовне середовище.

Мета статті - виявити та проаналізувати лексичні запозичення у складі ДФО, зафіксованих у художніх творах західноукраїнських письменників кінця XIX - початку XX ст., простежити взаємодію української мови з іншими національними мовами, з'ясувати шляхи запозичення.

Джерельною базою послугували ДФО, вибрані із творів 
Л. Мартовича, В. Стефаника, Г. Хоткевича, М. Черемшини.

Лексичний склад будь-якого говору української мови генетично строкатий. Крім основної маси лексики говіркової та загальнонародної, в ньому $\epsilon$ певний пласт більше чи менше адаптованих запозичень, оскільки будь-яка мова функціонує й розвивається у взаємозв'язках з іншими мовами.

На думку Ю.Ф.Прадіда, лексичний склад і форма фразеологізмів «дозволяє припустити існування мовних контактів їх носіїв з іншими слов'янськими і неслов'янським народами на різних етапах історичного розвитку» [6, с. 45$]$.

Протягом багатьох століть на території Західної України відбувалися контакти між українською, румунською, молдавською, угорською, польською, турецькою та німецькою мовами. Міжмовні контакти не могли не позначитись на розвиткові українських говірок. Оскільки фразеологічна система $\epsilon$ незамкненою, то в українські діалекти проникло немало експресивних запозичень. Зокрема, В. А. Чабаненко наголошує, що «окремі з них набувають експресивних якостей на українському мовному грунті. Чим глибше запозичення проникає в українське діалектне середовище, тим більшої семантикостилістичної трансформації воно зазнає» [12, с. 274].

Суттєвою ознакою ДФО, зафіксованих у творах Л. Мартовича, В. Стефаника, Г. Хоткевича, М. Черемшини, $\epsilon$ наявність у їх компонентному складі лексичних запозичень із польської, німецької, румунської мов. Узаємодія 3 іншими мовами створювала відповідне тло, на якому чіткіше усвідомлювалися самобутні ознаки української мови, відтворювані місцевими діалектами.

Діалектні компоненти у складі ДФО виявляють зв'язок із польською мовою. Найчастіше полонізми виконують роль граматично залежних одиниць та виступають засобом експресії, наприклад: діал. не мати за ніц - літ. мати за ніщзо «зневажати кого-небудь, не рахуватися $з$ кимсь» [10, с. 471]: Робив таку політику, щз мужиків не мав за ніщ, попам не кланявся та мав великий жаль до Польщзі $і$ до начальника станиії (Стеф., с. 249), пор.: польське nic - «ніщо, нічого» [5, с. 632]; діал. запри г’ямбу - літ. затулити рота «примушувати кого-небудь замовкати, не давати змоги висловитися» [10, с. 319]: Пий та запри собі г'ямбу, бо в мене забава (Стеф., с. 126), пор.: польське gemba - «рот» [5, с. 726].

У поданих прикладах відчутно додаткові конотативні нашарування семантики фразеологізмів: у першому мікроконтексті за допомогою ДФО не мати за ніц автор передає емоційно-негативне ○ О. В. Дехтярьова, 2013. 
ставлення до героїв твору. Другий мікроконтекст ілюструє іронічне ставлення мовця до персонажа новели.

Чільне місце серед експресем-запозичень посідають германізми в компонентному складі ДФО: діал. нема рихmy «не мати права» [4, с. 18]: Я собі без тебе раду дала, я собі торби пошила та й межи люди пішла. Як-єм з торбов за твій поріг переступила та й я вже не твоя газдиня, нема рихту (Стеф., с. 87); За своє $n$ 'ю, ніхто до того рихму не має (Стеф., с. 13), пор.: нім. das Recht - «право» [7, с. 331]; діал. на гиндель пускати «пускати на продаж»: $A$ то ж бог не гніваєси на таких, шо землю на гиндель пускают (Стеф., с. 67), пор.: нім. die Handel «торгівля» [4, с. 39]; діал. місити обцасами «не припиняти, не переставати бити» [4, с. 36]: Кажут, шо болото зробив з жінки. А рано вона хотіла втечи, але ймив та привєзав та місив обцасами, як у глину. Най бог боронит від такого! (Стеф., с. 83), пор.: нім. der Absatz «закаблук», слово запозичене тільки в одному 3 кількох значень [7, с. 150]; діал. буде капуm «хто-небудь може померти, загинути» [4, с. 49]: Слабував я тогди довго, гадав, щзо вже буде капут (Стеф., c. 169), пор.: нім. kaputt - «розбитий, зіпсований» [7, с. 368]; діал. упаласи у лєцтий рід «потрапити до найбіднішого хазяїна» [4, с. 18]: Не кривдуйси на мні, моя Чічко, не кривдуй, шо ти упаласи в пусті руки, у лєцтий рід (Черемш., с. 110), пор.: нім. letzt - «останній» [7, с. 325]; діал. на вандер «ходити без діла, тинятися» [9, с. 45]: Краньцуовські приходили радо до Матчуків через те, щуо ніде більше не бували, бо жонцова, одно, щуо соромилася за наліг свого мужа, а друге, ї̈ муж мав таку вдачу, щзо як випив чарку горілки, то зараз його збирало «на вандер» (Март., с. 200), пор.: нім. wandern - «блукати, мандрувати» [4, с. 41]. Українська форма 3 початковим м (мандри) виникла, очевидно, внаслідок регресивної дисиміляції в дієслівній основі вандрував.

Одним iз шляхів проникнення германізмів стала військова повинність, яку відбувала чоловіча частина населення Західної України в польській, а згодом в австрійській арміях. Військові германізми запозичувались безпосередньо 3 німецької через австрійську та німецьку армії. Це наказово-командні слова, назви солдатської амуніції, ступенів військової ієрархії. Вони були відомі чоловікам, які були в складі згаданих армій. Решта населення їх майже не вживала, наприклад: діал. втети итерна (штерна - знак розпізнавання молодшого командного складу [9, с. 673]) «звільнити 3 військової служби»: - То, пане, чоловік боїтьси аби не прошкробав, аби штерна не втєли, бо то пани не люб'є мужиків, ніби руснаків, шо так називаєси (Стеф., с. 168), пор.: нім. die Sterne - «зірки» 
[7, с. 134]. Однак у наведеному контексті письменник розширює значення ДФО - «звільнити зі служби, розжалувати».

Фіксуємо ДФО стояти гаптах «стояти як при військовій команді Habt Acht! (Уважно)» - габтахт [11, с. 203]: Нагаруйси иілий тиждень, та щзе у цееркові гаптах стій (Стеф., с. 33), пор.: нім. Нabt Acht - «струнко при військовій муштрі» [4, с. 17].

В. В. Акуленко наголошує, що «вплив німецької мови на українську відбувався й посилювався протягом усього періоду іiі становлення й розвитку як європейської. Німецька мова передавала сюди нові поняття та форми їх втілення» [1, с. 10].

У компонентному складі ДФО трапляються запозичення 3 румунської мови, напр.: діал. мати пізьму (пизму) - літ. мати зуб «сердитися, гніватися на кого-небудь» [10, с. 471]: А Головач діправдi мае любаску собі, і вна на него пизму мала в сериі (Хотк., с. 52); Узяв піп на мене пізьму, - говорив Грищь до жінки по якімось часі, вернувши від хреста (Март., с. 29); Таже я казати казав, коли ж бо має на мене nізьму (Март., с. 29); або ДФО здоймити пізьму «перестати сердитися, гніватися на кого-небудь»: Та й здоймеш пізьму з Митра та й не меш його кованим євангелєм по голові бити за то, ио в церкві відвернув рот від руки твоєї (Черемш., с. 135), пор.: румун. pizma - «гнів» [8, с. 186]; діал. мати путерю - літ. мати силу «впливати на кого-небудь, щонебудь, керувати діями когось» [10, с. 475]: Відтак все, щзо путерю має, у верітках та ліжниках маєтки двигає (Черемш., с. 122), пор.: румун. putere - «сила» [2, с. 159]; діал. накласти гачі «тремтіти від страху, перелякатися»: А шо? Оден лиш Довбуш си із'євив та й видиш, присів панок. А коби так, не дай Боже, їх кілька си з'євило - ого! Наклали би пани повні гачі... (Хотк., с. 215), пор.: румун. gасе - «штани» [3, с. 483]; діал. іти / піти на симбрилю (цимбрилю) «найматись на службу до когось; бути у наймах»: Я, дьидику, тілько винна, щэо-сми на симбрилю у місто пішла, шо-сми служила та й вас годувала. То я до вас прийшла у гості (Черемш., с. 84); - Ану, заткайси! Якби-с порєдний був дєдя, то би твої діти не ходили на цимбрилю (Черемш., с. 105), пор.: румун. simbrie - «служба у когось, наймитування» [2, с. 170].

Проникнення іншомовних слів у ДФО зазвичай відбувалося внаслідок більш-менш постійних безпосередніх контактів найрізноманітнішого характеру носіїв гуцульських та покутськобуковинських говірок із носіями сусідніх мов. Причому останні часто були посередниками при передачі слів із тієї мови, з носіями якої українське населення безпосередньо не контактувало чи мало контактувало. Так, наприклад, низка слів німецького походження проникла в ๑ О.В. Дехтярьова, 2013. 
галицько-буковинські говори через польське посередництво.

Серед ФО, у яких простежуються зв'язки української та польської фразеології 3 німецькомовним джерелом, варто назвати ДФО з дієсловом німецького походження трафиmu (від нім. treffen «влучати» [4, с. 45]). Воно належить до шару давніх германізмів: Може, скажете, щзо я й без того був би трафив на цую стежку? Воно правда, щуо в кого нема в голові розтулку й за дурну курку, тому й архієрейські ризи не поможуть (Март., с. 167) - пор.: вступати на стежку «розпочинати яку-небудь діяльність або починати вести певний спосіб життя» [10, с. 156].

ДФО иляк би трафив запозичена 3 польської мови через посередництво німецької та «уживається для вираження крайнього незадоволення або обурення ким-, чим-небудь, зневаги, зла до когось» [10, с. 966]. В аналізованих творах фіксується в різних граматичних варіантах: бодай (най, аби) мене (тебе, єго, їх, їі, ї, го) шлях(к) трафить (трафит): Ого, вже най того вола илях трафит, ио го корова б'є! - казав Іван (Стеф., с. 20); - А я до того париивого Срулика, бодай єго илях трафив (Стеф., с. 84); То сльози самі капають, бодай їх шлях трафив, - говорив Микитка, ловив жменею очі так, як ніс, і пирскав сльозами на землю (Март., с. 132). Контексти умотивовують уживання у складі ДФО запозичень. Тільки через контекст ДФО виявляє свою неповторність, емоційність, передає особливу атмосферу спілкування персонажів творів.

Отже, лексичні запозичення в компонентному складі ДФО засвідчують певну об'єктивну зумовленість і відбивають живомовні зв’язки носіїв української мови 3 сусідніми народами та їх культурами; відкривають можливості не лише для суто практичних досліджень,а й для теоретичного опрацювання проблем міжмовних взаємин на фразеологічному рівні.

\section{Література}

1. Акуленко В. В. Німецький вплив на розвиток української мови : проблеми методології / В. В. Акуленко // Мовознавство. - 1997. - № 1. - С. 12-19.

2. Гуцульські говірки : Короткий словник / НАН України. Інститут українознавства імені І. Крип'якевича ; [уклад. Г. Гузар, Я. Закревська та ін.]. - Львів, 1997. $-230 \mathrm{c}$.

3. Етимологічний словник української мови : у 7 т. / АН УРСР. Ін-т мовознавства ім. О. О. Потебні; Редкол. О. С. Мельничук (головний ред.) та ін. - К. : Наук. думка, 1982. - Т. 1 : А-Г / укл. : Р. В. Болдирєв та ін. - 1982. - 632 с.

4. Лопушанський В. М.Німецькомовні лексичні запозичення в говорах Західної України : [навч. посіб.] / В. М. Лопушанський, Т. Б. Пиц. - Дрогобич : Коло, 2000. - 68 с.

5. Польсько-український. Українсько-польський словник : $[100000$ слів і 
словосполучень] / укл. А. Малецька. З. Ландовські. - К., Ірпінь : ВТФ «Перун», 2009. - 848 с.

6. Прадід Ю. Ф. Із спостережень над діалектною фразеологією (на матеріалі бойківських говірок) / Ю. Ф. Прадід // Мовознавство. - 1992. - № 5. - С. 44-47.

7. Русско-немецкий словарь : ок. 22000 слов / Е. Б. Линднер, М. А. Дарская, А. А. Лепинг, М. А. Сергиевская ; под ред. А. А. Лепинга. - [33-е изд., стереотип.]. М. : Рус. яз, 1988. - 528 с.

8. Словарь української мови : у 4-х т. / упор. Б. Грінченко. - К., 1907-1909.

9. Словник буковинських говірок / за заг. ред. Н. В. Гуйванюк. - Чернівці : Рута, 2005. $-688 \mathrm{c}$.

10. Фразеологічний словник української мови : у 2-х кн. / упоряд. В. М. Білоноженко та ін. - К. : Наукова думка, 1993. - 984 с.

11. Франко І. Я. Галицько-руські народні приповідки : у 3-х т. / І. Я. Франко. Львів : Наукове т-во ім. Т. Г. Шевченка, 1901-1910. - Т. 1 - 300 с.

12. Чабаненко В. А. Стилістика експресивних засобів української мови : [монографія] / В. А. Чабаненко. - Запоріжжя : ЗДУ, 2002. - 351 с.

\section{Джерела ілюстративного матеріалу}

Март. - Лесь Мартович Твори / Лесь Мартович. - К. : Дніпро, 1976. - 428 с.

Стеф. - Стефаник В. Повне зібр. творів : у 3-х т. / Василь Стефаник. - К., 1949. T. $1 .-377 \mathrm{c}$.

Хотк. - Хоткевич Г. Довбуш : [повість] / Гнат Хоткевич. - К. : Дніпро, 2004. - 392 с.

Черемш. - Черемшина М. Твори в двох томах / Марко Черемшина. - К. : Наукова думка, 1974. - Т. 1. - 336 с.

Стаття надійшла до редакції 14.11.2013 р. 